\title{
A DNA barcoding approach in the study of tardigrades
}

\author{
Michele CESARI, ${ }^{*}$ Roberto GUIDETTI, ${ }^{1}$ Lorena REBECCHI,${ }^{1}$ Ilaria GIOVANNINI, ${ }^{1}$ Roberto BERTOLANI ${ }^{2}$
}

\author{
${ }^{1}$ Dipartimento di Scienze della Vita, Università di Modena e Reggio Emilia, Via G. Campi 213/D, 41125 Modena; \\ ${ }^{2}$ Dipartimento di Educazione e Scienze Umane, Università di Modena e Reggio Emilia, Via A. Allegri 9, 42121 Reggio Emilia, Italy \\ *Corresponding author: michele.cesari@unimore.it
}

\begin{abstract}
DNA barcoding is a technique proposed by Hebert and co-workers in 2003 for discriminating species through analysis of a single gene barcode locus. It aims to obtain a better taxonomic resolution than that achieved through morphological studies, and to avoid the decline in taxonomic knowledge. Today DNA barcoding is a global enterprise, and the implementation of the idea has seen a rapid rise (more than 1900 papers published to date on different organisms). Nonetheless, controversy still arises regarding barcoding and taxonomy. It is important to note that DNA barcoding does not focus on building a tree-of-life or on doing DNA taxonomy, even though sometimes it has been used for these purposes. DNA barcoding rather focuses on producing a universal molecular identification key based on strong taxonomic knowledge that should be included in the barcode reference library. In the phylum Tardigrada, DNA barcoding represents a recent approach to species identification and to help in solving taxonomic problems, especially considering the diminutive size of these animals and the paucity of morphological characters useful for taxonomy. In the framework of the MoDNA Project (Morphology and DNA), carried out by our research group in collaboration with several colleagues, we are combining the study of a fragment of the mitochondrial cytochrome c oxidase subunit I gene (cox1) with morphological data, in a wide sense (cuticular structures, chromosomes, data on sex ratio and reproduction), to form an integrative taxonomy approach for tardigrade species identification. We believe that without verified reference sequences from voucher specimens that have been authenticated by qualified taxonomists, there is no reliable library for newly generated sequences with which to be compared. Methods and protocols for standardized results are focused on obtaining tight correspondence between tardigrade morphology (and egg shell morphology, when useful), possibly both light and scanning electron microscopy images, and molecular sequence. This approach is particularly useful in describing new species, and important when applied on material collected in species type localities. Results using this approach are presented, primarily focusing on a number of species from the so-called Macrobiotus hufelandi group.
\end{abstract}

Key words: cox1, integrative taxonomy, Tardigrada, Macrobiotus hufelandi group.

\section{INTRODUCTION}

DNA barcoding is a molecular and bioinformatics technique proposed by Paul Hebert et al. (2003a), which primarily uses a single gene sequence to identify species. This system promises to be a reliable, cost-effective and accessible solution to the problem of species identification, especially considering the increasing lack of expert taxonomists. Being 10 years old, it may be considered today as a well-funded, global enterprise (Taylor and Harris, 2012): a search on Scopus of all articles containing the phrase DNA barcod* returned 1907 papers that have been published thanks to its use. DNA barcoding may be used to tackle very different issues: controlling the identity of food of animal and/or vegetal origin, e.g. fishes for sale in supermarkets (Rasmussen et al., 2009), identifying immature specimens and resolving adult and larval stages within the same species (Hebert et al., 2004a; Paquin and Hedin, 2004; Greenstone et al., 2005; Hubert et al., 2010), studying extinct species (Lambert et al., 2005) and discriminating possible cryptic species (Hebert et al., 2004a, 2004b; Hogg and Hebert, 2004; Barrett and Hebert, 2005; Ward et al., 2005; Lara et al., 2010; Carolan et al., 2012).
The premise of DNA barcoding is based on the fact that a short sequence of nucleotides can act as a molecular marker (or DNA barcode) to discriminate the analysed taxa. In the case of animals, the most widespread barcode is a $\sim 650$ base pair stretch of the 5 ' portion of mitochondrial gene coxl, coding for the protein cytochrome c oxidase subunit I (COI). In order to act as reliable barcode, the genetic variability found in the target sequence must be higher between species than that found within species.

One of the most important innovations introduced by DNA barcoding is standardisation. Together with the introduction of reliable molecular markers, standardisation provides a generalization in the taxonomic world, which was only randomly present before, allowing researchers from different fields to share the same framework (Casiraghi et al., 2010). DNA barcoding data are meant to be easily accessed either in GenBank and/or in the Barcoding Of Life Database (BOLD). In order to achieve a uniformity of data present in the database, the DNA barcoding pipeline must follow precise protocols, from collecting species to storing molecular data, in order to produce reliable data that can lead to a universal molecular identification key. A keystone of DNA barcoding is the creation 
of a barcode reference library, in which molecular data must be integrated with reliable morphological taxonomic knowledge. Reference sequences lie therefore at the heart of the DNA barcoding initiative: without reference sequences from voucher specimens that have been verified by expert taxonomists, there is no reliable library with which newly generated sequences may be compared (Taylor and Harris, 2012). Therefore, rather than replacing traditional taxonomists, DNA barcoding actually reinforces the need for qualified expert taxonomists, who have to verify and validate morphological type specimens from which reference sequences are produced (Packer et al., 2009). The voucher specimens allow also the replication of results, making DNA barcoding a proper scientific discipline (Peterson et al., 2007).

In the frame of building a correct barcode reference library, the relationship between the produced barcoding sequences and the voucher specimens attached to each sequence must be well defined. A nomenclature has been established (Pleijel et al., 2008) defining the different kinds of relationships that vouchers have with respect to molecular sequences. These are, in order of descending accuracy: hologenophores, iso-/progenophores and paragenophores. More specifically, hologenophores are voucher specimens that are prepared from the same individual used for molecular analysis; iso-/progenophores are voucher specimens that are in parent-offspring relationship with the individual used for molecular analysis (isogenophores are in asexual relationships with the study organism, while progenophores are in sexual relationships); paragenophores are individuals sampled at the same time and in the same locality as the ones used for molecular analyses.

In the phylum Tardigrada, the diminutive size of the animals and the paucity of morphological characters that can be used for taxonomy represent a difficult challenge for the study of these meiofauna metazoans. DNA barcoding has been a useful help in solving taxonomic problems within the phylum (Cesari et al., 2009; Bertolani et al., 2011a, 2011b), even though some adjustments had to be invented in order to satisfy the standardisation required by this technique (Cesari et al., 2011). This paper represents our undertaking of DNA barcoding to tardigrades, as carried out in the framework of the MoDNA (Morphology and DNA) project. The final aim of this project was to combine the results obtained with molecular analysis with the morphological data in a wide sense (cuticular structures, including egg shell, chromosomes, gametes, sex ratio, reproductive modes, etc.), in order to form an integrative taxonomy of tardigrades.

\section{METHODS}

Tardigrades are occasionally present in the same sample with mixed cryptic species, characterised by indistinguishable morphology (Faurby et al., 2008, 2011; Guil and Giribet, 2009; Bertolani et al., 2010, 2011a, 2011b). Therefore, tardigrade genomic DNA extraction for DNA barcoding must be performed only on single individuals. Being also small animals, normally ranging from 0.1 to 1 $\mathrm{mm}$, genetic analysis may be complicated, as the amount of obtained DNA is a limiting factor. However, a rapid salt and ethanol precipitation protocol (Cesari et al., 2009) can easily be applied to these animals and/or their eggs, yielding a sufficient amount of DNA (an average of 4 $\mathrm{ng} / \mu \mathrm{L}$ in $16 \mu \mathrm{L}$ final volume) to perform a few amplifying reactions and also to be stored for eventual successive comparisons. Usually, amplification of coxl gene can be achieved by using universal primers (Cesari et al., 2009; Bertolani et al., 2010, 2011a, 2011b), though in some cases specific primers must be designed to obtain reliable results (Cesari et al., 2011). Furthermore, all obtained sequences must be carefully examined, inspecting especially for insertion-deletions (or indels), in frame stop codons and nucleotide composition (Song et al., 2008). This is an unavoidable step in barcoding analysis, as the amplification of defective copies of the mitochondrial gene (or pseudogenes) exported to the nuclear genome (numts) is a distinct possibility (Rubinoff et al., 2006).

Tardigrade voucher specimens connected to the DNA barcoding analysis should be obtained. Paragenophores are usually the easiest to obtain and certainly provide useful information, but one should be extremely careful and avoid using them as the lone source of morphological information (see comments above on mixed cryptic species). Paragenophores are especially valuable if other methods of investigations can be carried out. For example, scanning electron microscopy photos and karyological analyses provide very useful information on the morphology and reproductive strategy of the target species. In any case, paragenophores, even though useful, never guarantee the correspondence between morphology and DNA sequence. The images of paragenophores presented in this paper have been obtained by directly mounting specimens with FaureBerlese fluid on slide, fixing specimens with Carnoy fluid (methanol-acetic acid 3:1) and then staining them with acetic lactic orcein, or preparing them for scanning electron microscopy (SEM) observations. Animals and eggs mounted in Faure-Berlese fluid and animals stained with orcein have been observed by light microscopy (LM) and photographed at the Laboratory of Evolutionary Zoology of the Department of Life Sciences (University of Modena and Reggio Emilia), using a Leitz DM RB microscope with phase $(\mathrm{PhC})$ and differential interference (DIC) contrast, equipped with a digital camera Nikon DS-Fi 1. For SEM preparation, animals and eggs were first boiled in absolute ethanol, then desiccated by evaporation of boiling absolute ethanol, mounted on stubs and sputter-coated with goldpalladium (Guidetti et al., 2000; Bertolani et al., 2011b). They were examined under a FEI XL 40 SEM (Fei Com- 
pany, Hillsboro, OR, USA - Oxford Instruments, Abingdon, UK) at the Centro Interdipartimentale Grandi Strumenti of the University of Modena and Reggio Emilia.

The preparation of hologenophore voucher specimens is particularly delicate for tardigrades, as their diminutive size, as already stated, requires the use of the entire animal for DNA extraction. In order to circumvent this issue, two methods can be used for obtaining this type of voucher specimens (Bertolani et al., 2010, 2011a, 2011b; Cesari et al., 2011). With the first method, pictures of each tardigrade are collected before using it for DNA extraction (Fig. 1a). To avoid movements during image capture, one can freeze at $-20^{\circ} \mathrm{C}$ the animal that will be examined (this may kill the animal, but it preserves its tissues). After thawing, it will be put in a drop of distilled water between coverglass and slide, and photos taken of valuable morphological characters at maximum magnification $(100 \times$, immersion oil; microscope and camera, see above). The animal is later used for molecular analysis. Alternatively, especially for species where the ornamented eggshell is useful to discriminate species, one can collect eggs from the sample, put them in individual bowls with mineral water at $15^{\circ} \mathrm{C}$, wait for their hatching, and use the eggshell as a voucher specimen, while the newborn is used for molecular analysis (Fig. 1b).

However, the type of voucher specimens that can lead to the largest amount of information for tardigrades is the iso-/progenophore. In fact, when a true rearing system is not possible (most cases), females with eggs can be separated in individual bowls with mineral water at $15^{\circ} \mathrm{C}$ until they lay their eggs. Remember that egg laying occurs often but not always. Subsequently, the adult female is mounted as a voucher (or, alternatively, it can be prepared for SEM investigations; for methods see above), while the eggs produced may follow different paths. When ornamented, some eggs are mounted as vouchers, while others are used for molecular analysis (even waiting for them to hatch). When smooth, they can be used for molecular analysis or for obtaining newborns to mount as voucher specimens. This protocol allows one to obtain information on both adults (or newborns) and eggs, and therefore it provides a complete morphological assessment on the analysed taxa (Fig. 1c).

Following the protocols described above, we have carried out a DNA barcoding investigation on several species of tardigrades. First of all, we present here, as paradigmatic examples, what kind of images can be obtained not only in Macrobiotus, the genus here considered as an example for DNA barcoding analysis and integrative taxonomy, but also on different types of voucher specimens mounted and in vivo belonging to various tardigrade families (Macrobiotidae, Hypsibiidae, Echiniscidae) and classes (Eutardigrada and Heterotardigrada), in order to have a general view of the possible morphological results. A more in depth DNA barcoding analysis with relationships between molecular data and morphology was then applied to different species of the Macrobiotus hufelandi group, which has been the target of our previous studies (Cesari et al., 2009, 2011; Bertolani et al., 2011a, 2011b) and for which extensive molecular data are available (Tab. 1). In the analysis we have included specimens collected in the loci typici of the species and we have also considered GenBank sequences belonging to the M. hufelandi group (Tab. 2), with the exception of $M$. persimilis (GenBank A.N. EU244608, unpublished, because a deletion is present at bp number 392, resulting in a stop codon, and therefore could be ascribed to a numt). Data were analysed for intraspecific, interspecific, and overall mean Kimura 2-parameters (K2P) distances using MEGA5 (Tamura et al., 2011). Considering that Srivathsan and Meier (2011) suggested that K2P may not increase the identification success in DNA barcoding, we also computed intraspecific, interspecific, and overall mean uncorrected $p$-distances using MEGA5. A neighbor joining (NJ) phenogram was computed on K2P distances using MEGA5, with bootstrap values obtained after 2000 replicates. Minimum spanning network analysis between haplotypes was performed by using Arlequin 3.1 (Excoffier et al., 2005) and visualized by using HapStar (Teacher and Griffiths, 2011). A parsimony network among haplotypes was also computed by applying the method described by Templeton et al. (1992), as implemented in TCS 1.21 (Clement et al., 2000).

The images of the specimens also analysed from a molecular point of view have been submitted to BOLD for their availability to all scientists.

\section{RESULTS}

Images of voucher specimens of species belonging to different tardigrade families are here presented (Figs. 2-8), not always for correlating images and DNA sequences, but for showing what kind of morphological result can be obtained for this phylum thanks to our proposed methodology. Images of vouchers connected to the sequences produced for DNA barcoding were produced for almost all examined populations of the Macrobiotus hufelandi group (Figs. 6 and 7). We also present paragenophore vouchers (Figs. 2-4). These were prepared by mounting specimens for optical microscopy (Fig. 2), for scanning electron microscopy (Fig. 3) and by staining them for karyological analyses (Fig. 4). Furthermore, both hologenophore (in vivo specimens, Figs. 5 and 6; and shells of ornamented eggs, Fig. 7) and iso-/progenophore (Fig. 8) voucher specimen information are presented. Figs. 5,6 and 8 depict hologenophore and iso-/progenophore voucher specimens of tardigrade species of other taxonomic groups, namely Pseudechiniscus facettalis Petersen, 1951, Bryodelphax parvulus Thulin, 1928, Echiniscus blumi Richters, 1903 (Echiniscidae), Diphascon brevipes (Marcus, 1936) (Hypsibiidae) and Macrobiotus cf. persimilis (Macrobiotidae), with the aim to 
prove what kind of morphological information can be obtained in different tardigrade taxa. For these species, cox 1 sequences were obtained, but they were not included in present molecular analysis, because they are still under investigation.

The analysis of the M. hufelandi group was focused on individuals belonging to five morphospecies (Macrobiotus hufelandi C.A.S. Schulze, 1834; Macrobiotus sandrae Bertolani \& Rebecchi 1993; Macrobiotus macrocalix Bertolani \& Rebecchi 1993; Macrobiotus terminalis Bertolani \& Rebecchi 1993; and Macrobiotus vladimiri Bertolani, Biserov, Rebecchi \& Cesari, 2011) and sampled in six different localities (Tab. 1). The molecular dataset here considered comprised 64 total sequences that ranged from 519 to $624 \mathrm{bp}$. No analysed sequence contained indels and/or stop codons, making them unbiased of numt interference. Alignment analysis revealed average nucleotide base frequencies as $\pi_{\mathrm{A}}=0.290, \pi_{\mathrm{T}}=0.352, \pi_{\mathrm{G}}=0.156$ and $\pi_{\mathrm{C}}=0.203$. The average number of barcoded specimens for each sample was 9.7 (standard deviation=6.2, range: $5-17$ specimens). The overall mean genetic distances were comparable: K2P: $16.9 \%$ and $p$-distance: $14.6 \%$.

As shown in the distribution of frequency of K2P distances (Fig. 9), intraspecific comparisons were generally

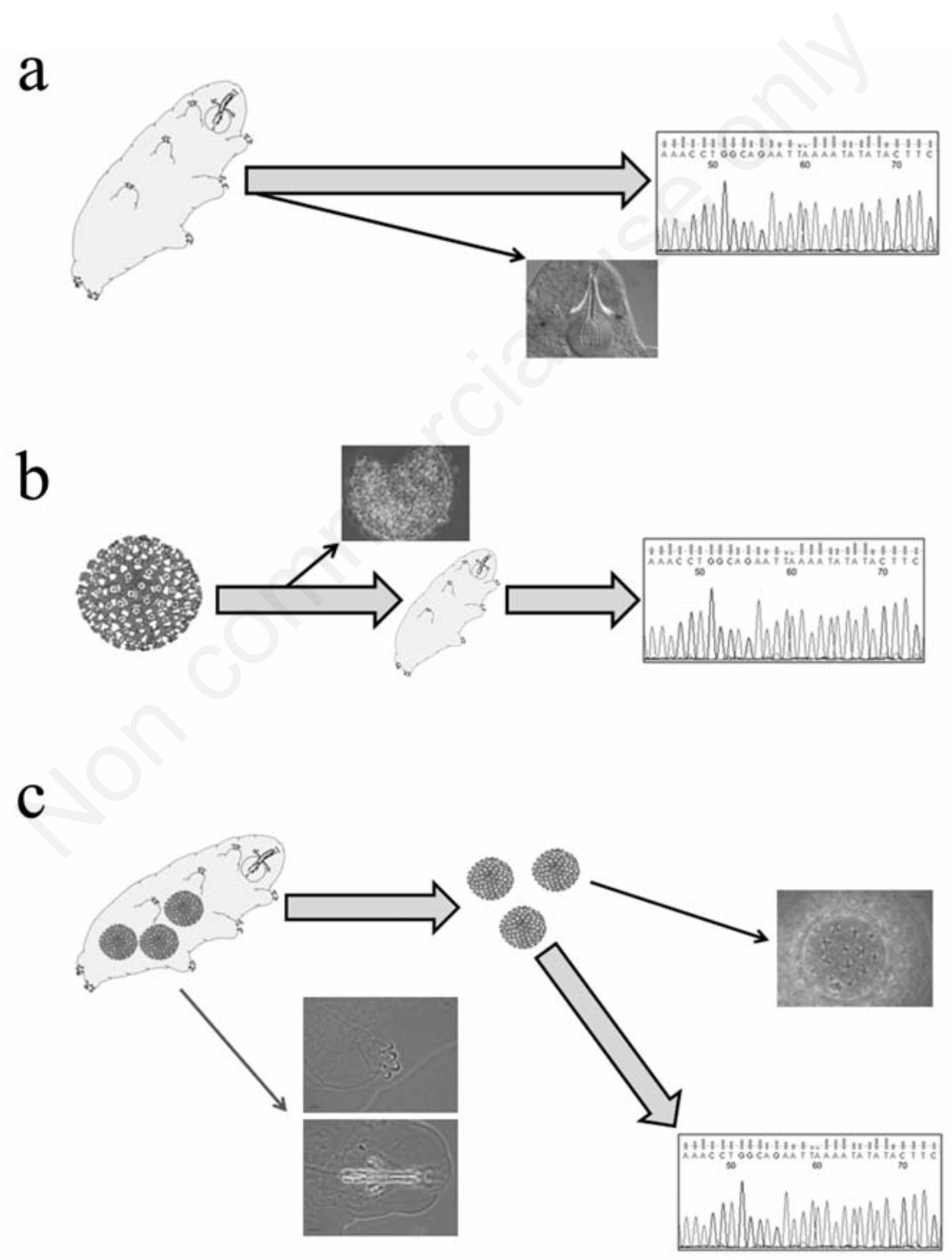

Fig. 1. Voucher specimen preparation in tardigrades. a) Hologenophore, prepared by taking photos of the animal before utilising it for DNA extraction; b) hologenophore, prepared by isolating single ornamented eggs. After the hatching, the eggshell is mounted on slide with permanent mounting medium, while the newborn is used for DNA extraction; c) iso-/progenophores, prepared by isolating a female with eggs. Once the eggs are laid, the adult and an egg are mounted on slides with permanent mounting medium, while eggs or eventual newborns are utilised for molecular analysis. Voucher definitions as described by Pleijel et al. (2008). 
Tab. 1. Sequences belonging to species of the Macrobiotus hufelandi group produced in compliance with DNA barcoding standards.

\begin{tabular}{|c|c|c|c|c|c|}
\hline Morphospecies & Specimen & Location & $\begin{array}{c}\text { Accession } \\
\text { number }\end{array}$ & $\begin{array}{l}\text { Haplo- } \\
\text { type }\end{array}$ & Reference \\
\hline Macrobiotus terminalis & MOD: BRT: C2868 A01 V1** & Castelsantangelo, Italy & JN673958 & $\mathrm{H} 1$ & $\mathrm{D}$ \\
\hline \multirow[t]{4}{*}{ Bertolani \& Rebecchi, 1993} & MOD: BRT: C2868 N02 US2*0 & Castelsantangelo, Italy & JN673959 & H1 & $\mathrm{D}$ \\
\hline & $\mathrm{C} 2868{\mathrm{~A} 03^{*}}^{*}$ & Castelsantangelo, Italy & JN673960 & $\mathrm{H} 1$ & $\mathrm{D}$ \\
\hline & MOD: BRT: C2868 N04 US10*0 & Castelsantangelo, Italy & JN673961 & $\mathrm{H} 1$ & $\mathrm{D}$ \\
\hline & MOD: BRT: C2868 N05 US12*o & Castelsantangelo, Italy & JN673962 & H1 & $\mathrm{D}$ \\
\hline Macrobiotus vladimiri & $\mathrm{C} 2688 \mathrm{~A} 01^{*}$ & Andalo, Italy & HM136931 & $\mathrm{H} 2$ & $\mathrm{C}$ \\
\hline \multirow[t]{4}{*}{ Bertolani, Biserov, Rebecchi \& Cesari, 2011} & $\mathrm{C} 2688 \mathrm{~A} 02^{*}$ & Andalo, Italy & HM136932 & $\mathrm{H} 2$ & $\mathrm{C}$ \\
\hline & C2945 A01 & St. Ulrich, Germany & HM136933 & $\mathrm{H} 2$ & $\mathrm{C}$ \\
\hline & MOD: BRT: C2946 N01 US6 & St. Ulrich, Germany & HM136934 & $\mathrm{H} 2$ & $\mathrm{C}$ \\
\hline & C2688 E01* & Andalo, Italy & HQ876568 & $\mathrm{H} 2$ & $\mathrm{~B}$ \\
\hline Macrobiotus sandrae & C2688 A04 & Andalo, Italy & HQ876566 & H3 & $\mathrm{B}$ \\
\hline \multirow[t]{15}{*}{ Bertolani \& Rebecchi, 1993} & C2688 E03 & Andalo, Italy & HQ876567 & H3 & $\mathrm{B}$ \\
\hline & MOD: BRT: C2726 N01 US2 & Andalo, Italy & HQ876569 & $\mathrm{H} 4$ & $\mathrm{~B}$ \\
\hline & MOD: BRT: C2726 N02 US6 ${ }^{\circ}$ & Andalo, Italy & HQ876570 & H5 & $\mathrm{B}$ \\
\hline & $\mathrm{C} 2726 \mathrm{~A} 05$ & Andalo, Italy & HQ876572 & $\mathrm{H} 4$ & $\mathrm{~B}$ \\
\hline & C2726 A06 & Andalo, Italy & HQ876573 & $\mathrm{H} 4$ & $\mathrm{~B}$ \\
\hline & C2945 A02* & St. Ulrich, Germany & HQ876574 & H6 & $\mathrm{B}$ \\
\hline & C2945 A03* & St. Ulrich, Germany & HQ876575 & $\mathrm{H} 7$ & $\mathrm{~B}$ \\
\hline & C2945 A04* & St. Ulrich, Germany & HQ876576 & $\mathrm{H} 8$ & $\mathrm{~B}$ \\
\hline & $\mathrm{C} 2945 \mathrm{~A} 05^{*}$ & St. Ulrich, Germany & HQ876577 & H6 & $\mathrm{B}$ \\
\hline & C2945 A06* & St. Ulrich, Germany & HQ876578 & $\mathrm{H} 9$ & $\mathrm{~B}$ \\
\hline & $\mathrm{C} 2945 \mathrm{~A} 07^{*}$ & St. Ulrich, Germany & HQ876579 & H6 & $\mathrm{B}$ \\
\hline & MOD: BRT: C2945 N01 US1*0 & St. Ulrich, Germany & HQ876580 & $\mathrm{H} 7$ & $\mathrm{~B}$ \\
\hline & MOD: BRT: C2945 N02 US4*0 & St. Ulrich, Germany & HQ876581 & H6 & $\mathrm{B}$ \\
\hline & MOD: BRT: C2946 N02 US3 & St. Ulrich, Germany & HQ876582 & $\mathrm{H} 7$ & $\mathrm{~B}$ \\
\hline & MOD: BRT: C2946 N03 US7º & St. Ulrich, Germany & HQ876583 & $\mathrm{H} 7$ & $\mathrm{~B}$ \\
\hline Macrobiotus hufelandi & MOD: BRT: C2953 N01 US1*0 & St. Ulrich, Germany & HQ876584 & $\mathrm{H} 10$ & $\mathrm{~B}$ \\
\hline \multirow{13}{*}{ C.A.S. Schultze, 1834} & $\mathrm{C} 2953{\mathrm{~A} 01^{*}}^{*}$ & St. Ulrich, Germany & HQ876585 & H11 & $\mathrm{B}$ \\
\hline & $\mathrm{C} 2953 \mathrm{~A} 02^{*}$ & St. Ulrich, Germany & HQ876586 & $\mathrm{H} 12$ & $\mathrm{~B}$ \\
\hline & C2953 A03* & St. Ulrich, Germany & HQ876587 & H11 & $\mathrm{B}$ \\
\hline & C2953 A04* & St. Ulrich, Germany & HQ876588 & H11 & $\mathrm{B}$ \\
\hline & $\mathrm{C} 2953 \mathrm{~A} 05^{*}$ & St. Ulrich, Germany & HQ876589 & $\mathrm{H} 13$ & $\mathrm{~B}$ \\
\hline & C2959 A01 & Gotthard pass, Switzerland & HQ876590 & H14 & $\mathrm{B}$ \\
\hline & $\mathrm{C} 2959 \mathrm{~A} 02$ & Gotthard pass, Switzerland & HQ876591 & H15 & $\mathrm{B}$ \\
\hline & $\mathrm{C} 2959 \mathrm{~A} 03$ & Gotthard pass, Switzerland & HQ876592 & $\mathrm{H} 15$ & $\mathrm{~B}$ \\
\hline & C2959 A04 & Gotthard pass, Switzerland & HQ876593 & H15 & $\mathrm{B}$ \\
\hline & MOD: BRT: C2959 N01 US3 & Gotthard pass, Switzerland & HQ876594 & $\mathrm{H} 15$ & $\mathrm{~B}$ \\
\hline & $\mathrm{C} 2772 \mathrm{~A} 01$ & Rondinaio mountain, Italy & HQ876595 & $\mathrm{H} 15$ & $\mathrm{~B}$ \\
\hline & $\mathrm{C} 2772 \mathrm{~A} 02$ & Rondinaio mountain, Italy & HQ876596 & $\mathrm{H} 15$ & $\mathrm{~B}$ \\
\hline & $\mathrm{C} 2772 \mathrm{~A} 03$ & Rondinaio mountain, Italy & HQ876597 & H16 & $\mathrm{B}$ \\
\hline Macrobiotus macrocalix & $\mathrm{C} 2712 \mathrm{a}^{*}$ & Gaianello, Italy & FJ176203 & $\mathrm{H} 17$ & $\mathrm{~A}$ \\
\hline \multirow[t]{17}{*}{ Bertolani \& Rebecchi, 1993} & $\mathrm{C} 2712 \mathrm{~b}^{*}$ & Gaianello, Italy & FJ176204 & H17 & A \\
\hline & $\mathrm{C} 2712 \mathrm{c}^{*}$ & Gaianello, Italy & FJ176205 & H17 & $\mathrm{A}$ \\
\hline & $\mathrm{C} 2712 \mathrm{E}^{*}$ & Gaianello, Italy & FJ176206 & H18 & $\mathrm{A}$ \\
\hline & MOD: BRT: C2712 US3 ${ }^{* \circ}$ & Gaianello, Italy & FJ176207 & $\mathrm{H} 17$ & $\mathrm{~A}$ \\
\hline & $\mathrm{C} 2688 \mathrm{a}$ & Andalo, Italy & FJ176208 & H19 & A \\
\hline & $\mathrm{C} 2688 \mathrm{~b}$ & Andalo, Italy & FJ176209 & H19 & A \\
\hline & $\mathrm{C} 2688 \mathrm{c}$ & Andalo, Italy & FJ176210 & $\mathrm{H} 20$ & A \\
\hline & MOD: BRT: C2726 US1 ${ }^{\circ}$ & Andalo, Italy & FJ176211 & $\mathrm{H} 20$ & A \\
\hline & MOD: BRT: C2726 US3 ${ }^{\circ}$ & Andalo, Italy & FJ176212 & $\mathrm{H} 20$ & $\mathrm{~A}$ \\
\hline & C2726 A07 & Andalo, Italy & HQ876571 & $\mathrm{H} 20$ & $\mathrm{~B}$ \\
\hline & $\mathrm{C} 2728 \mathrm{a}$ & Andalo, Italy & FJ176213 & $\mathrm{H} 21$ & A \\
\hline & $\mathrm{C} 2728 \mathrm{~b}$ & Andalo, Italy & FJ176214 & $\mathrm{H} 21$ & A \\
\hline & $\mathrm{C} 2728 \mathrm{c}$ & Andalo, Italy & FJ176215 & $\mathrm{H} 21$ & A \\
\hline & $\mathrm{C} 2728 \mathrm{~d}$ & Andalo, Italy & FJ176216 & $\mathrm{H} 21$ & A \\
\hline & MOD: BRT: C2728 US1 ${ }^{\circ}$ & Andalo, Italy & FJ176217 & $\mathrm{H} 21$ & A \\
\hline & MOD: BRT: C2868 A06 V14 & Castelsantangelo, Italy & JN673963 & $\mathrm{H} 22$ & $\mathrm{D}$ \\
\hline & $\mathrm{C} 2868 \mathrm{~A} 07$ & Castelsantangelo, Italy & JN673964 & $\mathrm{H} 23$ & $\mathrm{D}$ \\
\hline
\end{tabular}

*Specimens sampled in type localities; ${ }^{\circ}$ sequences paired with hologenophore voucher specimens (Cesari et al., 2009; Bertolani et al., 2011a, 2011b; Cesari et al., 2011). 
Tab. 2. GenBank sequences belonging to Macrobiotus hufelandi group used in the analysis.

\begin{tabular}{lccc}
\hline Species & Accession Number & Haplotype & Reference \\
\hline M. gr. hufelandi & AY598773 & H24 & Guidetti et al., 2005 \\
M. gr. hufelandi & AY598774 & $\mathrm{H} 23$ & Guidetti et al., 2005 \\
M. terminalis & AY598775 & $\mathrm{H} 25$ & Guidetti et al., 2005 \\
M. gr. hufelandi & FJ435804 & $\mathrm{H} 2$ & Guil and Giribet, 2009 \\
M. gr. hufelandi & FJ435805 & H2 & Guil and Giribet, 2009 \\
M. gr. hufelandi & FJ435806 & H2 & Guil and Giribet, 2009 \\
\hline
\end{tabular}
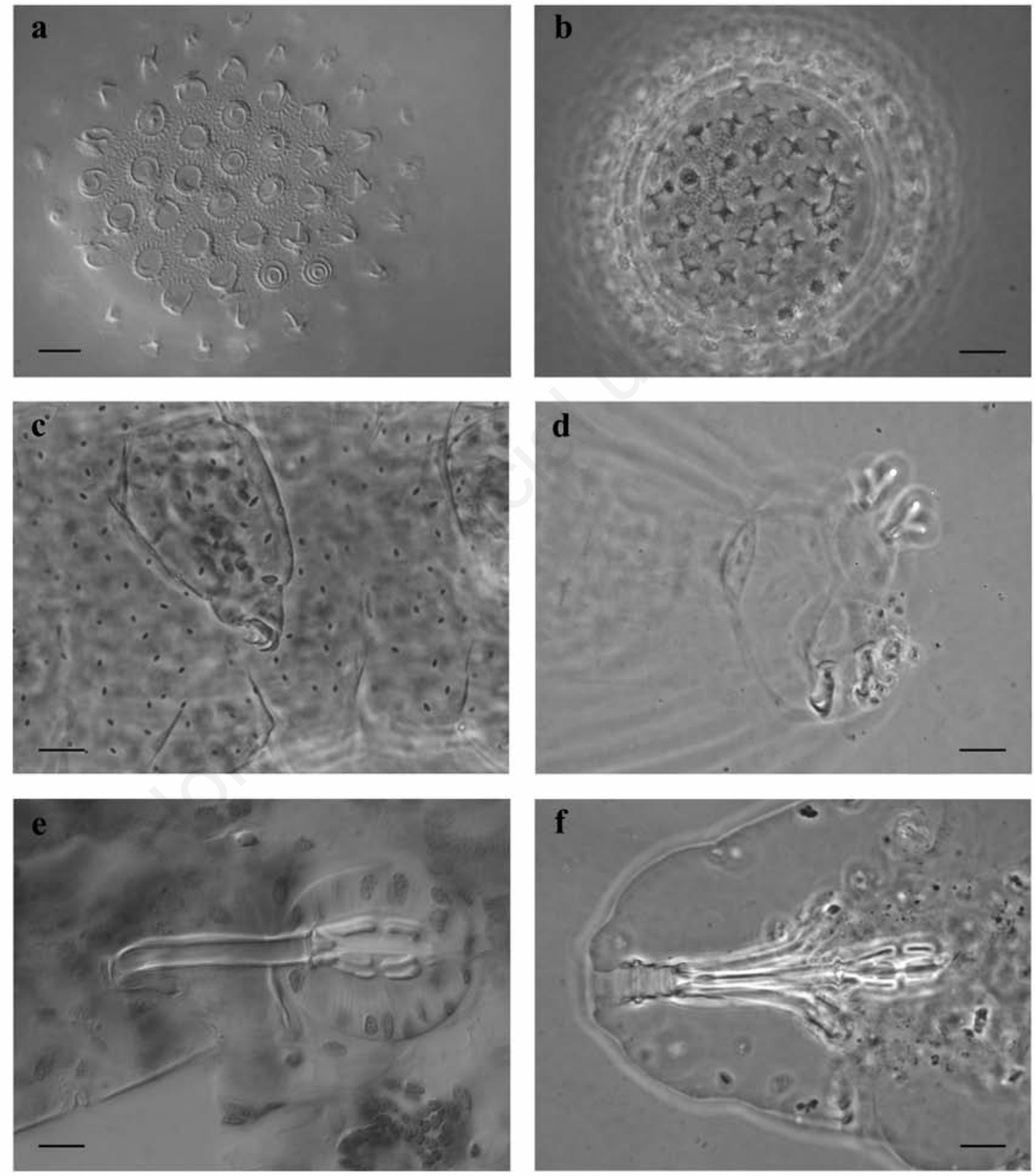

Fig. 2. Paragenophores from type localities by light microscopy. a) Egg of M. vladimiri from Andalo, Italy [Faure, microscope with differential interference contrast (DIC)]; b) egg of M. hufelandi from St. Ulrich, Germany [Faure, microscope with phase contrast (PhC)]; c) cuticle and leg of $M$. sandrae with pores from St. Ulrich, Germany (orcein, PhC); d) fourth pair of legs and claws of M. terminalis from Castelsantangelo, Italy (Faure, PhC); e) buccal-pharyngeal apparatus of M. terminalis from Castelsantangelo, Italy (orcein, DIC); f) buccal-pharyngeal apparatus of $M$. hufelandi from St. Ulrich, Germany. Note the evident constriction in the first macroplacoid (Faure, $\mathrm{PhC}$ ). Scale bars $=10 \mu \mathrm{m}$. 
between 0.000 to 0.013 , with higher values $(0.064-0.076)$ scored only in comparisons between individuals belonging to the morphospecies M. hufelandi. Apart from this last particular case, no overlap of interspecific and intraspecific distances occurred across the entire M. hufelandi group (Fig. 9). When the species were morphologically distinguishable, even for small details, interspecific comparisons never showed values lower than 0.179 .

Comparisons with sequences found in GenBank pointed out that sequences AY598773-4 should be ascribed to $M$. macrocalix (K2P and $p$-distances: $0.0-1.0 \%$ ), while sequences FJ435804-6 should be ascribed to M. vladimiri (they share the same haplotype). On the other hand, sequence AY598775, labeled as M. terminalis, was very differentiated with respect to $M$. terminalis sequences from specimens sampled in the type locality (K2P mean distance: 23.5\%, mean $p$-distance: $20.0 \%$; Tab. 3).

Mean genetic distances (Tab. 3) scored between specimens belonging to the same morphospecies were low (0$0.6 \%$, while those scored between different species were generally very high (K2P: $18.5-26.2 \%$; $p$-distance: 16.1 -
$21.9 \%$ ), with the cited exception of the specimens attributed to $M$. hufelandi (K2P: 6.7\%; p-distance: $6.3 \%$ ). The NJ dendrogram computed on all analysed sequences (Fig. 10) showed seven distinct groups, each supported by high bootstrap values $(100 \%)$, corresponding to the groups described above (all morphospecies, with the exception of M. hufelandi specimens, and the AY598775 sequence labeled as M. terminalis). The minimum spanning haplotype network and parsimony network confirmed the existence of the seven groups in the dendrogram (M. terminalis, $M$. cf. hufelandi sp. 1, M. hufelandi (sensu stricto), M. macrocalix, $M$. terminalis AY598775, M. vladimiri, and M. sandrae). Haplotype diversity inside each species varied considerably, ranging from 1 haplotype (M. vladimiri and M. terminalis) to 8 different haplotypes (M. macrocalix).

\section{DISCUSSION}

Our results demonstrate that the DNA barcoding technique can successfully be applied to tardigrades. Considering that the whole animal must be utilised for the DNA
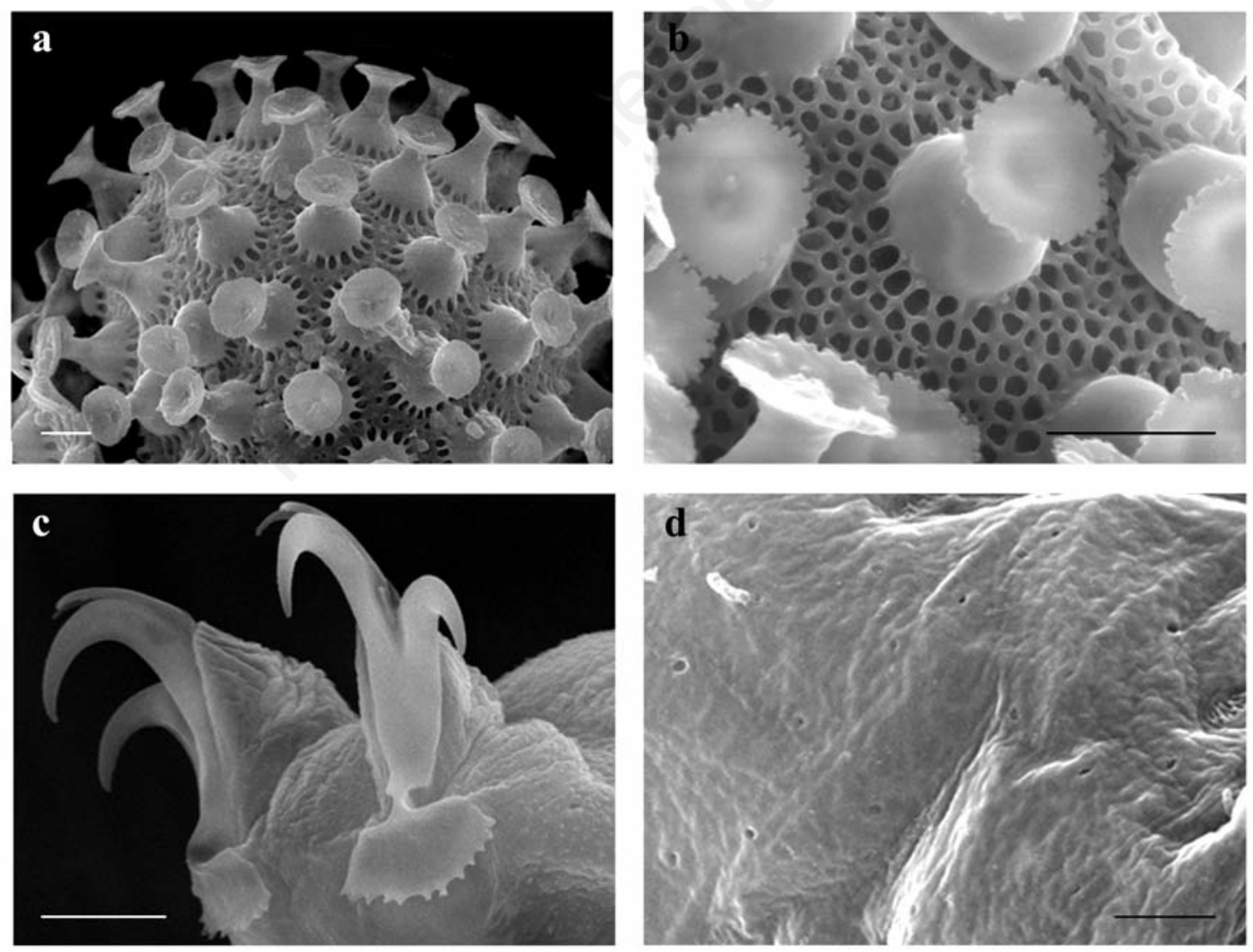

Fig. 3. Paragenophores by scanning electron microscopy. a) Egg of M. macrocalix from Andalo, Italy; b) detail of the egg of $M$. sandrae from type locality; c) fourth pair of legs with indented lunules of $M$. cf. polonicus, from Paris, France; d) cuticle with pores of $M$. cf. sapiens from Formigine, Italy. Scale bars $=5 \mu \mathrm{m}$. 
extraction, with our images and methods we demonstrate that integrating a well defined morphology, and therefore accurate morphological identifications, with a molecular sequence is possible in tardigrades. This can be obtained thanks to hologenophores and pro-/isogenophores, obtained by applying the techniques for voucher preparation to different tardigrade species, families and classes. When these vouchers are represented by microphotographs, we recommend publishing them in a data bank such as BOLD (www.barcodinglife.com), MorphoBank (mammaltree.informatics.sunysb.edu), Tardigrada Register (currently under construction), or others. These results undoubtedly

Tab. 3. Mean genetic distances computed among (below the diagonal: Kimura 2-parameters; above the diagonal: $p$-distance) and inside (columns K2P and P, respectively) species of the Macrobiotus hufelandi group taxa. All haplotypes are included in the analysis, which was carried out on $624 \mathrm{bp}$ dataset.

\begin{tabular}{lcccccccccc}
\hline & 1 & 2 & 3 & 4 & 5 & 6 & 7 & K2P & P \\
\hline 1 & M. terminalis & & 0.197 & 0.197 & 0.190 & 0.200 & 0.203 & 0.193 & 0.000 & 0,000 \\
2 & M. cf. hufelandi sp. 1 & 0.230 & & 0.063 & 0.177 & 0.190 & 0.219 & 0.187 & 0.001 & 0,001 \\
3 & M. hufelandi & 0.230 & 0.067 & & 0.168 & 0.192 & 0.208 & 0.181 & 0.001 & 0,001 \\
4 & M. macrocalix & 0.221 & 0.204 & 0.191 & & 0.161 & 0.193 & 0.169 & 0.006 & 0,005 \\
5 & M. terminalis AY598775 & 0.235 & 0.221 & 0.224 & 0.182 & & 0.181 & 0.163 & np & np \\
6 & M. vladimiri & 0.240 & 0.262 & 0.244 & 0.226 & 0.212 & & 0.181 & 0.000 & 0,000 \\
7 & M. sandrae & 0.225 & 0.216 & 0.208 & 0.193 & 0.185 & 0.210 & & 0.006 & 0,006 \\
\hline
\end{tabular}

$n p$, not possible (only one sequence was present).
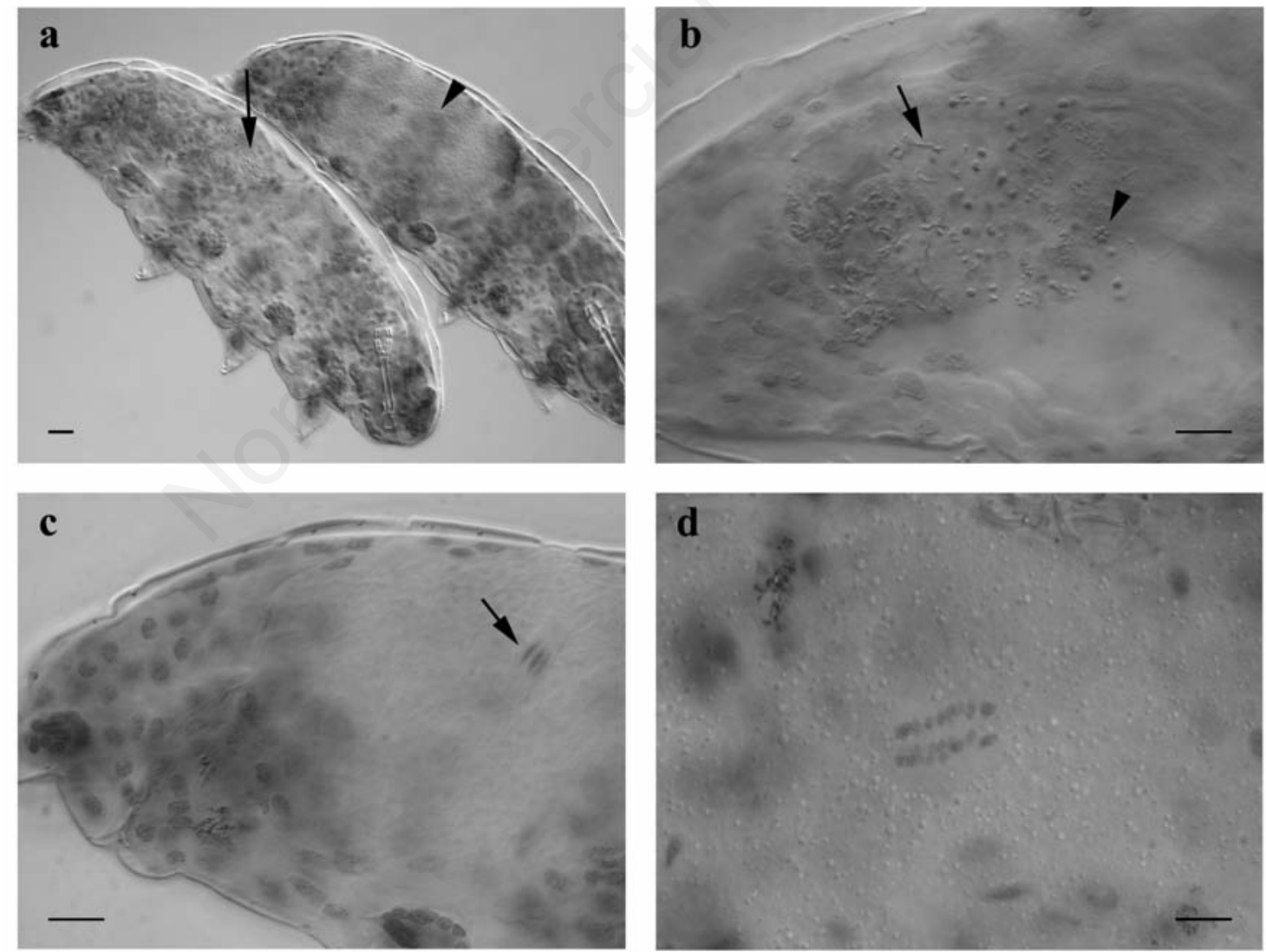

Fig. 4. Paragenophores for gender and chromosome identification by staining with orcein (light and differential interference contrast microscopy). a) Male (left) and female (rigth) of $M$. sandrae from type locality; arrow head indicates the oocytes, arrow indicates the spermatozoa within the testis; b) testis of $M$. sandrae from type locality; arrow indicates a spermatozoon, arrow head indicates a male meiotic metaphase; c) a diploid oocyte metaphase (arrow) in $M$. sandrae from type locality; d) a polyploid oocyte metaphase in $M$. terminalis from type locality. Scale bars $=10 \mu \mathrm{m}$. 
increase our taxonomic knowledge, allowing a better and more detailed species definition. Worthy of note is the importance of sampling in the species' type localities: this allows us to produce a barcode sequence linked to specimens representing, very probably, the effective species found in that place. This is an important feature for building a dependable DNA barcode reference library, and it can also be very helpful in defining the biogeographic distribution pattern of the species. Our method, based on a standardized protocol of DNA barcoding and a rational utilization of GenBank sequences, allows one to discriminate intra- and interspecific variability and suggests when new species should be described. These aspects are discussed in the following sections, together with an evaluation on the use of trees in DNA barcoding.

\section{The standardised protocol of DNA barcoding}

Several techniques were developed in order to obtain
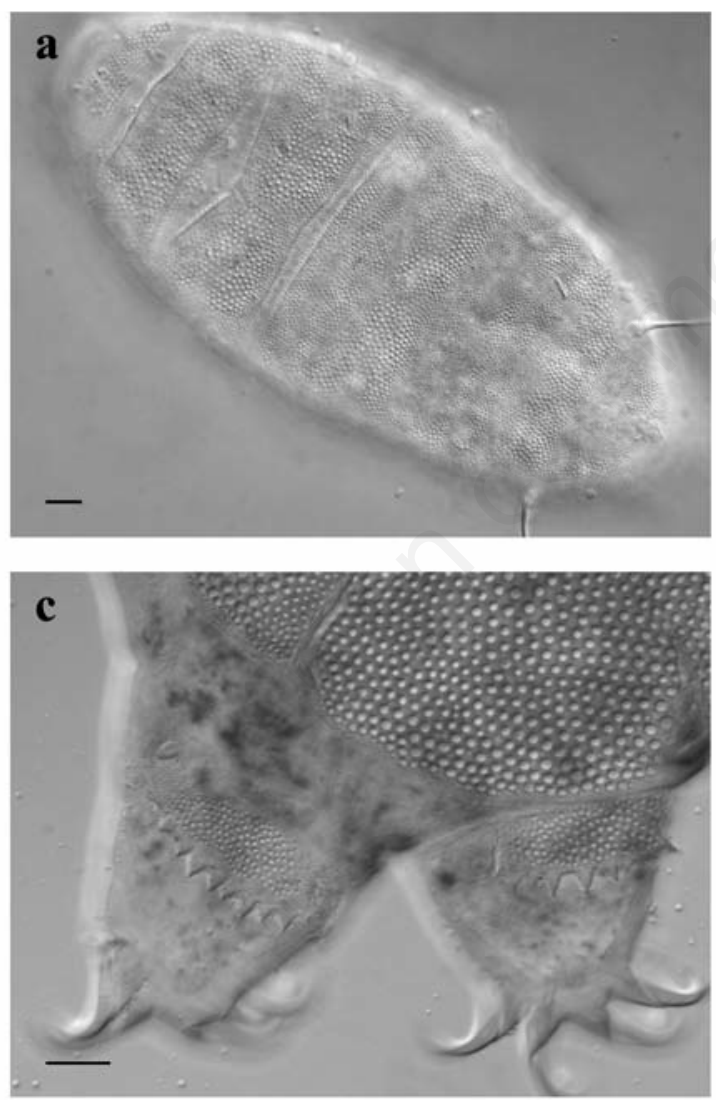

a reliable link between specimens analysed with molecular techniques and their morphology (Cesari et al., 2009, 2011; Bertolani et al., 2010). This is very important, especially in very small animals in which the scarcity of morphological characters (or our inability to observe them) can lead to difficulties in discriminating taxa and to misidentifications where cryptic species occur. Our morphological results from different tardigrade taxa (different families and different classes; Figs. 2-8) demonstrate what kind of images can be obtained in indirect as well as direct relationship with the DNA sequences. We should note that the images taken as vouchers must be of high quality, especially in the case of hologenophores, when it is not possible to prepare slides as vouchers that will be accessible to other researchers. These integrated morphological and molecular techniques may also be applied to other meiofauna and microfauna metazoans that pose similar problems in the study of their taxonomy.
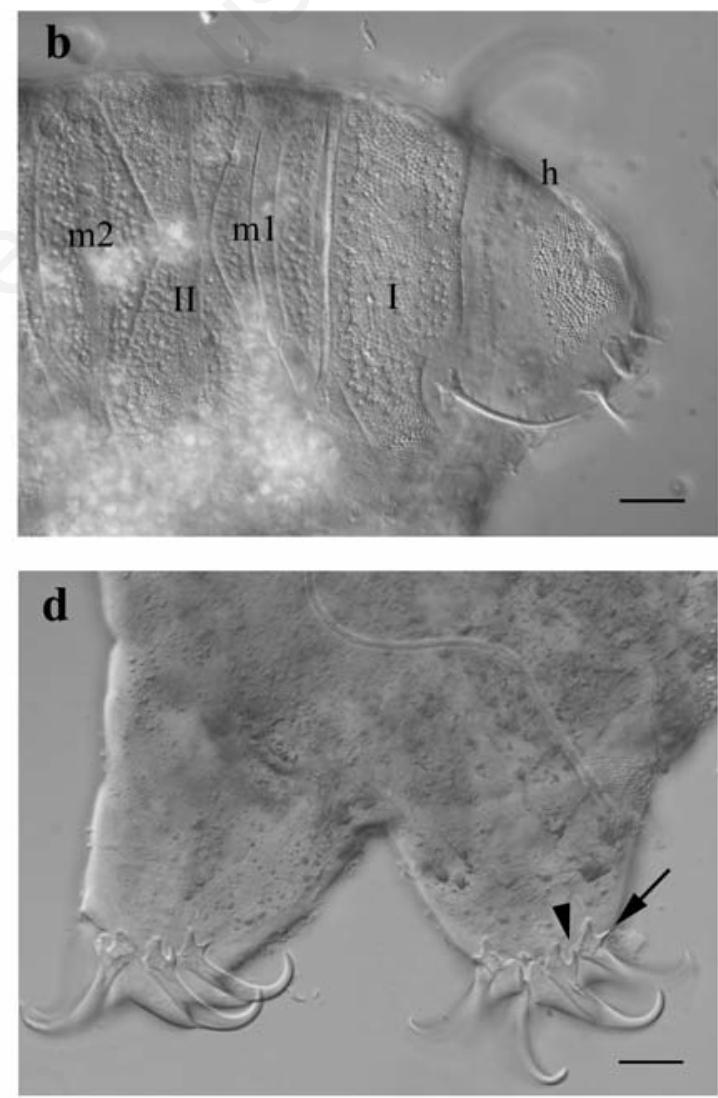

Fig. 5. Images of hologenophores in vivo of Heterotardigrada (light and differential interference contrast microscopy). a) Pseudechiniscus facettalis from Carvalhal da Moita do Conqueiro, Portugal, dorsal cuticle with plates and sculpture (MOD: BRT: C3040 V1); b) Bryodelphax parvulus from Carvalhal da Moita do Conqueiro, Portugal; head (h) and anterior plates: scapular (I), paired plates II (II), median plates ( $\mathrm{m} 1$ and $\mathrm{m} 2$ ); note the double sculpture of the cuticle (MOD: BRT: C3042 V04); c-d) terminal plate and legs IV of Echiniscus blumi from Castro Laboreiro, Portugal at different focuses (c, dorsal view; and d, ventral view); note the kind of sculpture and the dentate collar in c and the different kinds of spurs in the internal (arrow head) and external (arrow) claws in d (MOD: BRT: C3247 V12). Scale bars $=10 \mu \mathrm{m}$. 

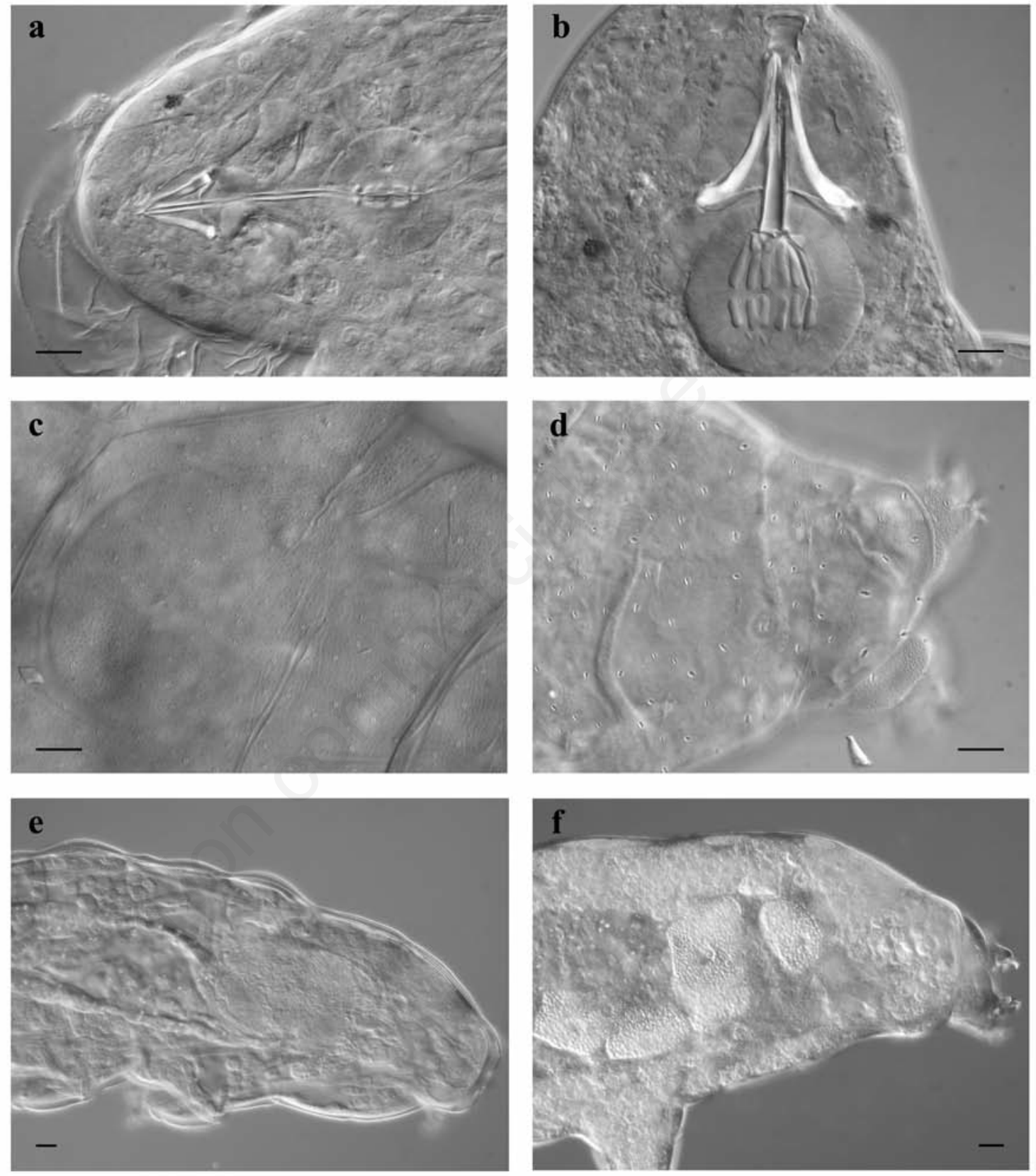

Fig. 6. Images of hologenophores in vivo of Eutardigrada (light and differential interference contrast microscopy). a) Buccal-pharyngeal apparatus of Diphascon brevipes (MOD: BRT: C2703 D. brevipes V1); b) buccal-pharyngeal apparatus of M. terminalis from Castelsantangelo, Italy (MOD: BRT: C2868 A01 V1; Acc. No. JN673958); c) cuticle of M. terminalis from type locality; other than pores note the fine granulation, omitted in the original description (MOD: BRT: C2868 A01 V1; Acc. No. JN673958); d) caudal cuticle and IV legs of M. cf. macrocalix from Carvalhal da Moita do Conqueiro, Portugal (MOD: BRT: C3041 V07; Acc. No. JX683816); e) testis containing spermatozoa and spermatids in M. cf. macrocalix from Castro Laboreiro, Portugal (MOD: BRT: C3247 V02; Acc. No. JX683820; f) ovary containing oocytes in M. cf. macrocalix from Castro Laboreiro, Portugal (MOD: BRT: C3247 V08; Acc. No. JX683811). Scale bars $=10 \mu \mathrm{m}$. 
The Consortium for the Barcode of Life (CBOL), GenBank and BOLD require seven mandatory characteristics to be attached with the produced sequence in order to consider the produced data as complying with the DNA barcoding standard (Hanner, 2009). All these were included in our data preparation and are: i) a unique identifier for voucher specimens (please follow the rules stated in the Registry of Biological Repositories site; www.biorepositories.org); ii) name of species (the name given to the specimen analysed for DNA barcoding may be provisional in order to increasing access and accelerating data release); iii) country where the specimen has been collected; iv) an accepted barcode region; v) PCR primers utilised; vi) sequence trace files (both forward and reverse trace files must be included in the barcode reference); vii) more than $75 \%$ readable bases must be contiguous within the accepted barcode region.

We strongly suggest one read and strictly follow these guidelines. Moreover, it should be noted that the locus used for DNA barcoding must satisfy three characteristics: it must be universal (i.e. it has to be routinely sequenced across organisms), it should produce good quality long and bidirectional sequences (with few or no ambiguous base calls) and it should allow discrimination of most species. In animals, the most widely used and reliable barcode region is the coxl gene. In some cases (Meier et al., 2006), however, cox 1 does not work as a barcode region, therefore some other markers can be proposed as a bar-
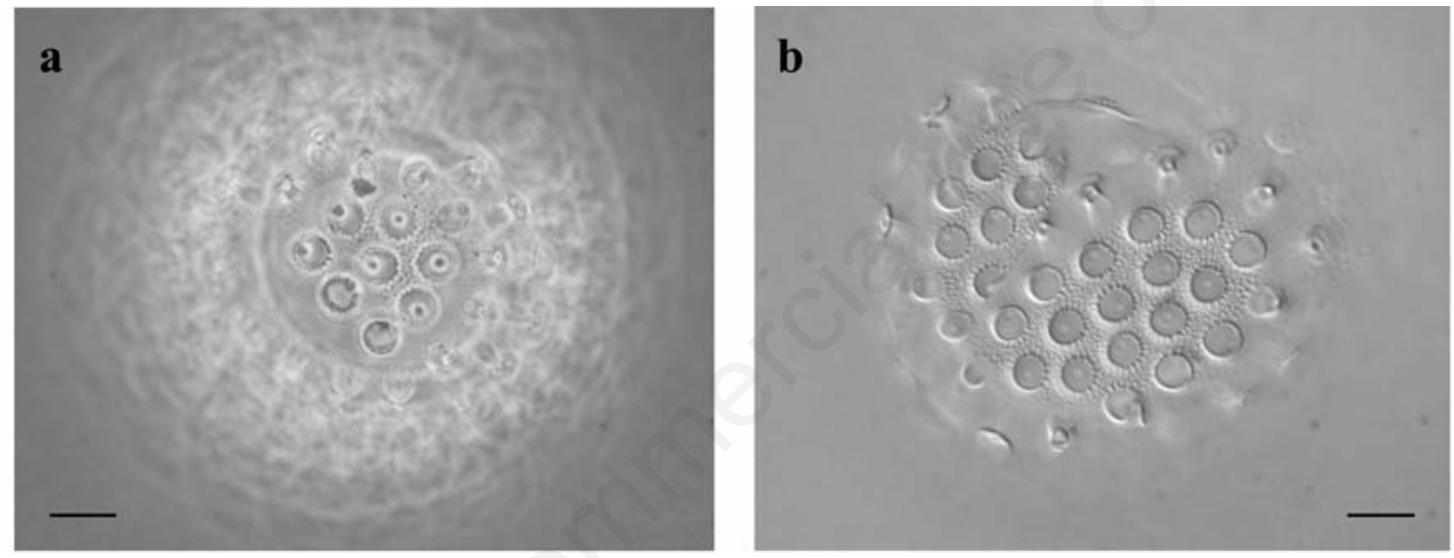

Fig. 7. Images of hologenophores (egg shells) (light microscopy, Faure). a) Egg shell by phase contrast microscopy of M. sandrae from its type locality (Germany) (MOD: BRT: C2946 N03 US7; Acc. No. HQ876583); b) egg shell by differential interference contrast microscopy of M. sandrae from its type locality (Germany) (MOD: BRT: C2946 N02 US3; Acc. No. HQ876594). Scale bars=10 $\mu$ m.
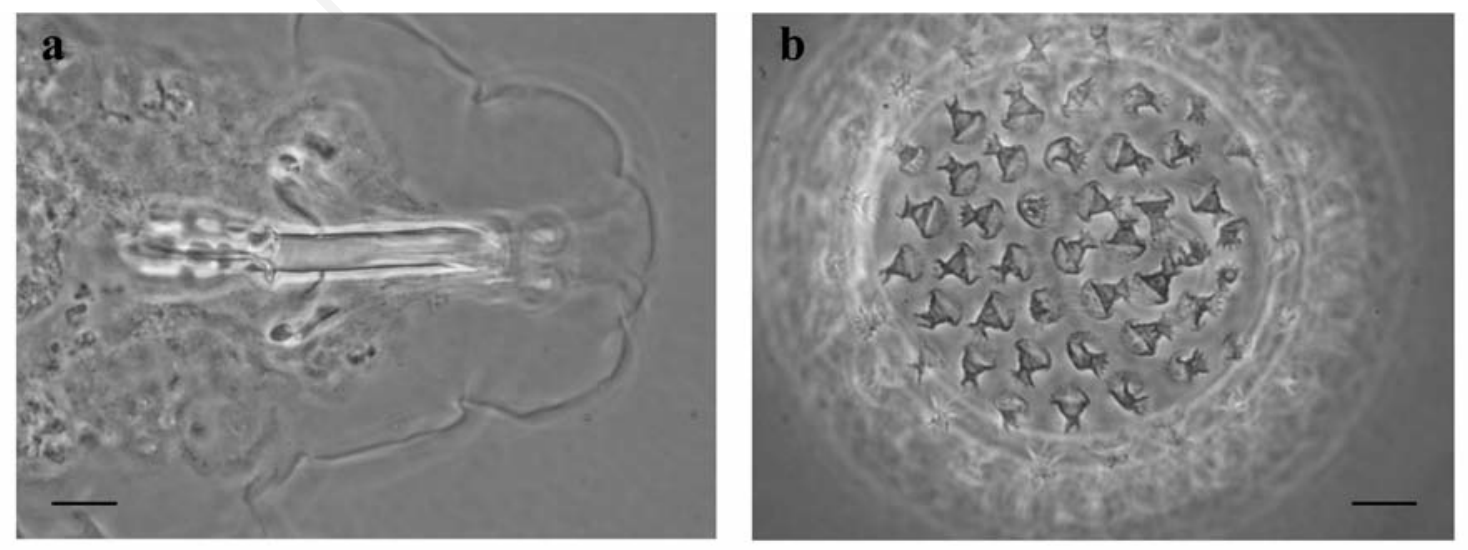

Fig. 8. Iso-/progenophores of $M$. cf. persimilis from Bernolda, Italy (animal and egg mounted in the same slide, MOD: BRT: C3282 FEM N) (light and phase contrast microscopy, Faure). a) Buccal-pharyngeal apparatus of a female; note the evident constriction of the first macroplacoid; b) her egg. Scale bars $=10 \mu \mathrm{m}$. 
code region. Universal primers should generally be used, as the philosophy of DNA barcoding assumes the possibility of amplifying with the same primers the same barcode region in different taxa. In some cases, however, some pitfalls can occur, as it may not be possible to amplify the barcode region for technical and biological reasons. Therefore, specifically designed primers (for tardigrades, Cesari et al., 2011) and/or primer cocktails may be used, as long as their sequences are included in the barcode reference.

Interestingly, the number of specimens that should be analysed is a feature not subject to restrictions. In fact, no consensus exists on how many individuals must be barcoded, nor is a minimal number stated. In a simulation of structured populations under coalescent and real species of skipper butterflies (Zhang et al., 2010) aimed at evaluating the variability of the investigated taxa, the optimal range that resulted was very wide (from 9.5 to 216.6). However, the population parameters can be affected by different biological factors, such as the population structure and its evolutionary history, and, moreover, available individuals may be scarce, as biodiversity is unevenly distributed and most species are small and naturally rare (Fontaine et al., 2007).
Usually, sample sizes ranging from 5 to 10 individuals with similar sequences for each putative species are considered satisfactory. In our case, the number of barcoded tardigrade specimens (a range of 5-17 specimens per sample) produced more than adequate results.

\section{Discriminating intra- and interspecific variability}

The amount of genetic difference that leads to discriminate two taxa in DNA barcoding has been a subject of discussions. The first attempt to define a threshold genetic distance value that would divide different taxa was done in one of the first barcoding papers (Hebert et al., 2003b), and the chosen value was a $p$-distance higher than $3 \%$ for lepidopterans. Later, however, another investigation on birds (Hebert et al., 2004b) defined this threshold value with the so-called 10-fold rule: the gap found between species must be a generic ten times higher than that found within species. This rule was strongly criticized and disapproved (Moritz and Cicero, 2004; Wiemers and Fiedler, 2007). Today the approach is less rigid, as the definition of a strict threshold value for all biological organisms makes little sense (Meier et al., 2008). Different authors (Lefébure et al., 2006; Ferri et al., 2009) formally tested

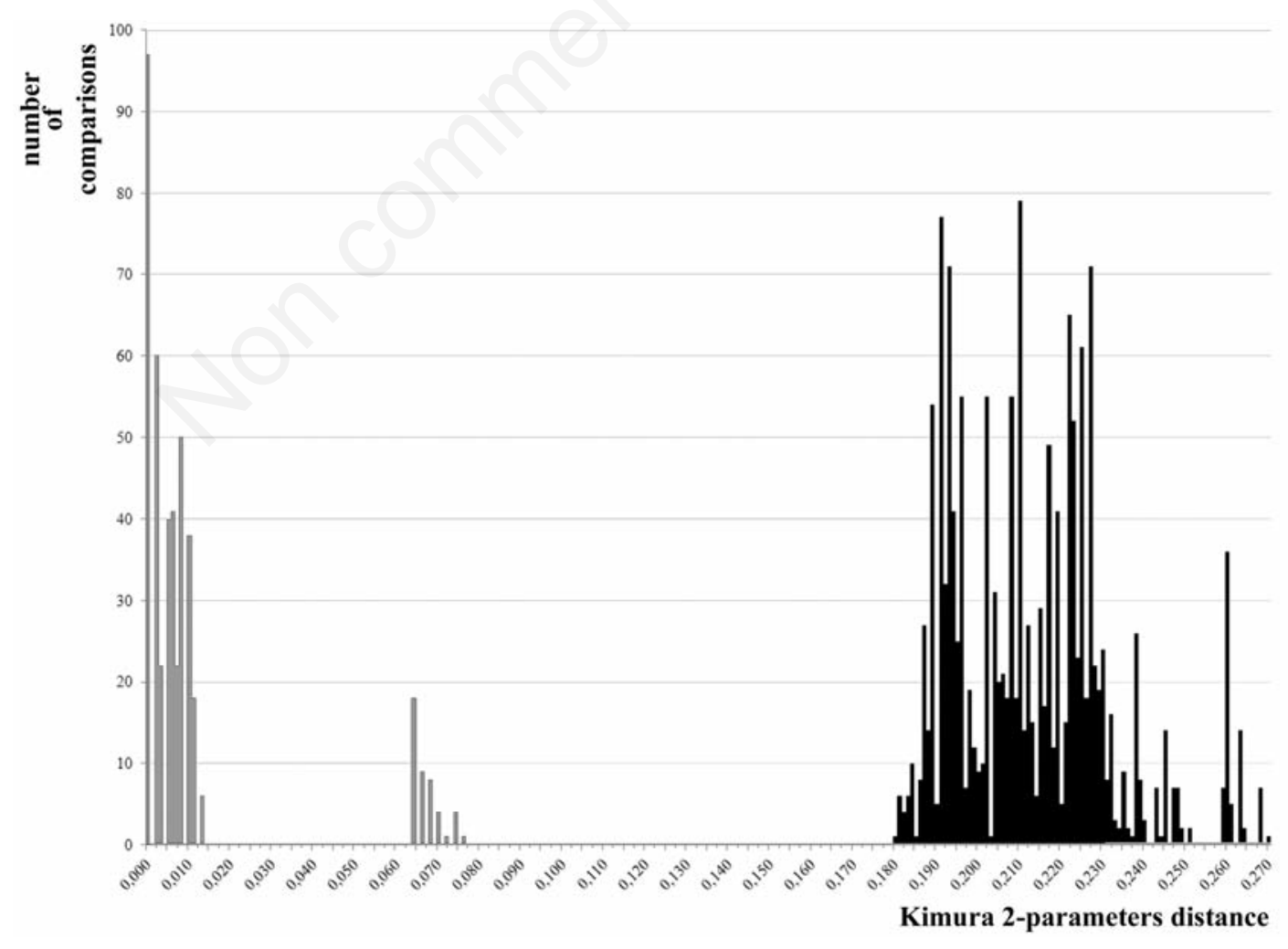

Fig. 9. Frequency distribution of each scored Kimura 2-parameters genetic distances in comparison with all the considered Macrobiotus hufelandi group sequences ( $\mathrm{n}=64$, Tab. 1). The graph shows 2016 total genetic comparisons, both intraspecific (grey, $\mathrm{n}=439)$ and interspecific (black, $\mathrm{n}=1577$ ). The attribution to the same or to a different species has been done on morphological basis. 
the correlation between taxonomic ranks and genetic distances, in order to assess the definition of a molecular threshold and found that there was a global agreement with the current taxonomy of the studied organisms. The threshold value may vary among different organisms, and it can be determined by comparing the values of K2P genetic distance found in intrataxa comparisons with those found in intertaxa ones. When the two types of comparisons do not overlap, this is the so-called DNA barcode gap. Moreover, Srivathsan and Meier (2011) suggested that $\mathrm{K} 2 \mathrm{P}$ may not increase the identification success in DNA barcoding, and $p$-distance should be used. In our analysis, both genetic distances performed very similarly in discriminating at least five different species belonging to the M. hufelandi group, with values of K2P and $p$-distances being very high in interspecific comparisons, while being very low in intrataxa comparisons (Tab. 3, Fig. 10). Moreover, no overlap between interspecific and intraspecific distances occurred (Fig. 9), indicating a high reliability of the barcoding technique in discriminating

\section{a}

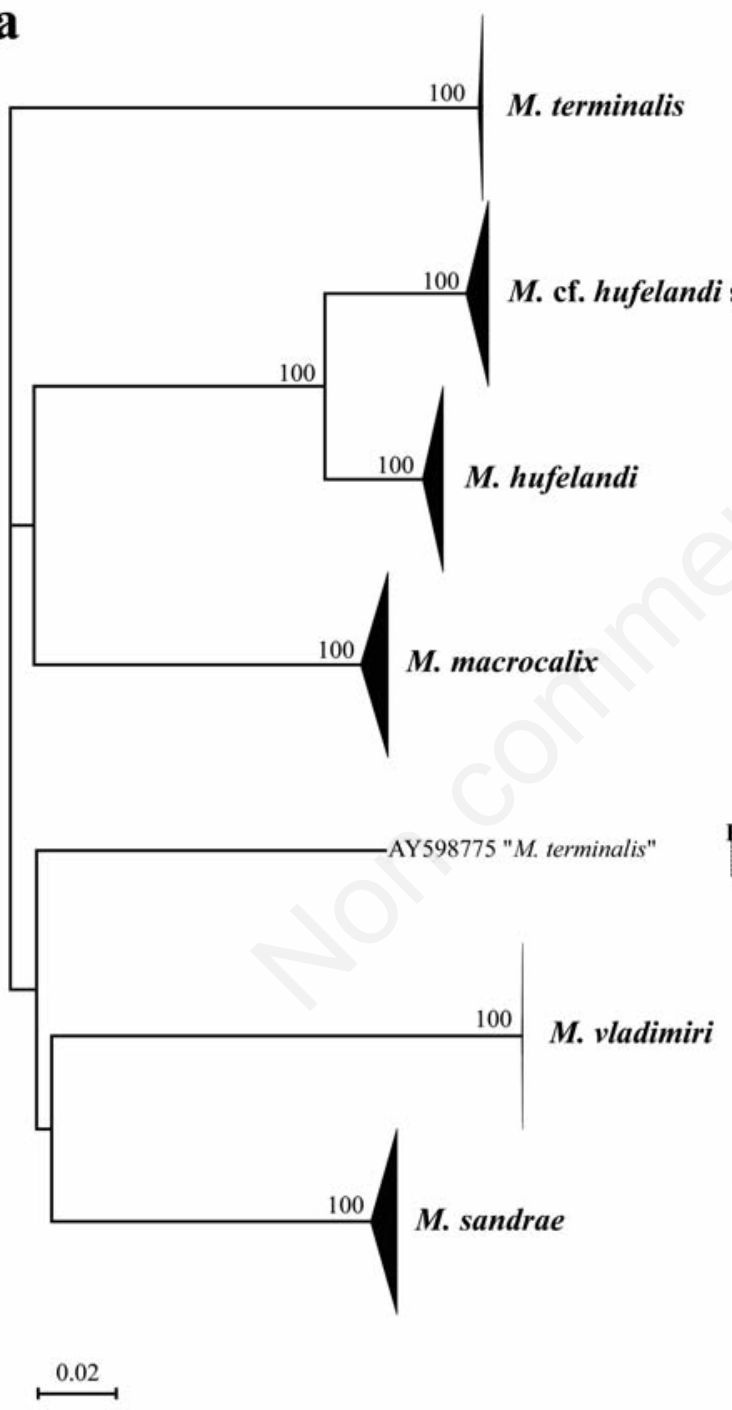

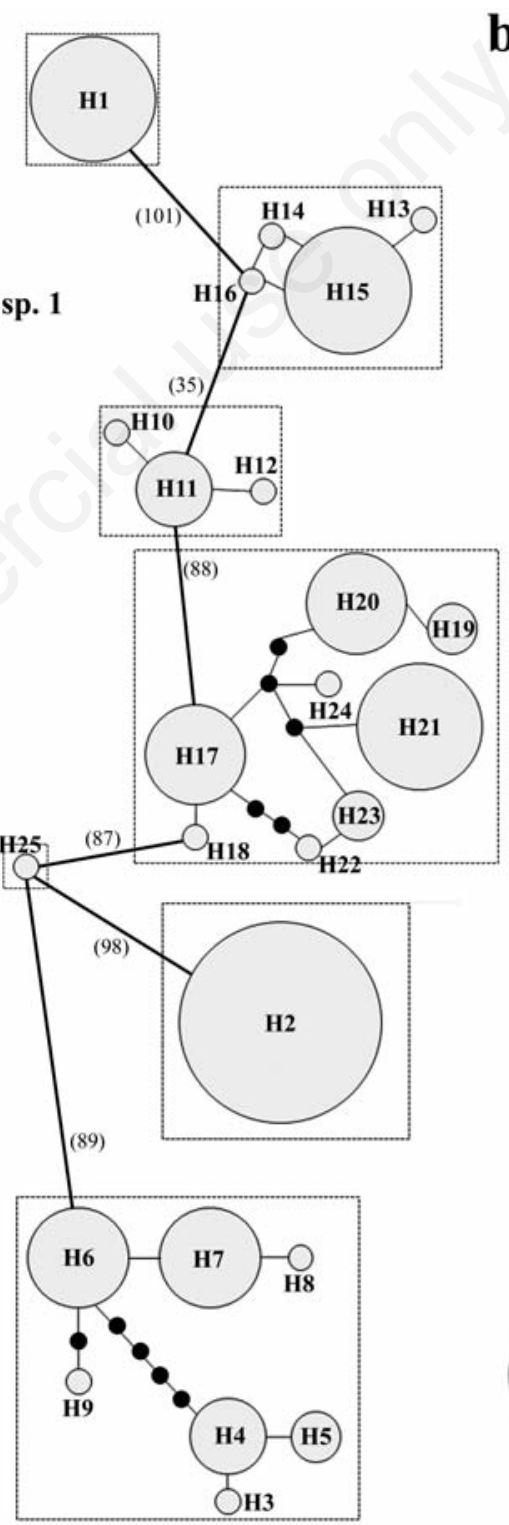

b

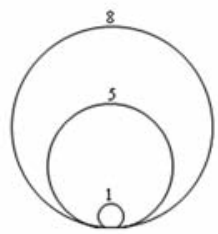

Fig. 10. Neighbour-joining dendrogram (a) and minimum spanning and parsimony network (b) computed on all 64 analysed sequences. Bootstrap percentages computed after 2000 replicates are shown above branches. Haplotypes are represented by circles with the area being proportional to their frequency of occurrence. Lines show single mutational events, while small filled circles denote missing/ideal haplotypes. Haplotype groups included in squares are supported by parsimony values $>95 \%$. 
different tardigrade taxa. Therefore, an attempt can be made to define a threshold value for taxa belonging to $M$. hufelandi group. Our data point out a very high difference between specimens showing different morphologies, a value always over 18.5 (K2P) or $16.2 \%$ ( $p$-distance). One only exception occurred, probably due to cryptic speciation. In one case genetic distances scored inside the same morphospecies, namely M. hufelandi, showed higher values with respect to those inside to the other species of the group, ranging from 6.4 to $7.6 \%(\mathrm{~K} 2 \mathrm{P})$ or 6.1 to $7.1 \%$ ( $p$ distance). One haplogroup was found only in the type locality of M. hufelandi (in Germany), while the other was found in the same locality (one specimen; HQ876589) and in several specimens (HQ8766590-7) in the Alps (Switzerland) and in the Apennines (Italy) (Bertolani et al., 2011b). We pointed out that these specimens could belong to a different and cryptic taxonomic entity, as no morphological differences were spotted. Other than by the genetic distance, our conclusion was also supported by the fact that parthenogenesis always occurred and therefore gene flow was not possible between the two haplogroups (Bertolani et al., 2011b). This can be defined also as an unconfirmed candidate species (UCS), defined as conspecifics which are differentiated only by genetic distances (Vieites et al., 2009; Padial et al., 2010). The UCS, named at the moment $M$. cf. hufelandi sp.1, could also be due to geographic variation, but it is important to underline it was found sympatrically with M. hufelandi in the type locality.

\section{DNA barcoding and GenBank sequences}

The inclusion of GenBank sequences in a DNA barcoding investigation is not devoid of possible pitfalls. In our case, one sequence had to be discarded, as it did not meet the required standards (presence of indels in a sequence belonging to M. polonicus). Unfortunately, many sequences in GenBank are not dependable in their taxonomical information, a fact that has already occurred in tardigrades (Guidetti et al., 2009). However, our DNA barcoding analysis allowed us to identify the remaining sequences coming from GenBank as belonging to two specific taxa, namely M. macrocalix (Cesari et al., 2009) and M. vladimiri (Bertolani et al., 2011a). The lone sequence that performed strangely was AY598775, labeled as M. terminalis by us in a previous phylogenetic study (Guidetti et al., 2005). Considering the facts that: i) this sequence has no linked information on its morphology (as it was not produced for DNA barcoding analyses); ii) it has high distance values with respect to M. terminalis specimens sampled in the type locality; and iii) it shares the same adult and egg morphology of the type material, it should provisionally be designated as $M$. cf. terminalis, until a better taxonomic determination and further investigations of other specimens from the same site are performed. We presume that if we find further ma- terial with the same or a similar sequence, we will easily identify a new species, characterizing it (if the material is sufficiently abundant) from several points of view, including its sex ratio, reproductive strategy and maybe chromosome number. This underscores again the importance of integrating morphological and molecular results in order to gain more comprehensive information (i.e. integrative taxonomy).

\section{Describing new species}

Our results confirmed that alpha-taxonomy based on morphological data can find great support from molecular studies when conducted with well standardized protocols. The application of DNA barcoding facilitated the process of describing a new species, namely M. vladimiri, and delineating its chromosome number and reproductive mechanisms (Bertolani et al., 2011a). The use of DNA data is certainly not a revolutionary approach in taxonomy, but there are two major aspects in which DNA barcoding can really be useful. The first, and probably most important, is the use of DNA barcoding as a tool to discriminate between species, which can be viewed as an equivalent to species identification or species diagnosis (DeSalle et al., 2005). The second is the utilization of DNA data to create hypotheses regarding new species (Goldstein and DeSalle, 2011), as an equivalent to species description. Regarding the second use, the first papers on DNA barcoding actually proclaimed the possibility of describing new species without any other information (Hebert et al., 2003a, 2003b, 2004b). Recently, however, the use of DNA barcoding alone to describe a new species has been tempered. Rather, it should be considered a tool to speed species description (Kress and Erickson, 2008) and/or to flag potential new species (Hajibabei et al., 2011). Describing new species without any corroborating evidence other than a single locus DNA sequence of mitochondrial origin should be strongly avoided (DeSalle, 2006). Indeed, new species have to be described with as many taxonomic characters as possible (Galimberti et al., 2012) and in an integrative framework, considering also morphological, geographical and ecological data when available.

\section{DNA barcoding and trees}

Finally, it is important to underline that DNA barcoding is an identification method and not a phylogenetic one (Casiraghi et al., 2010). The use of a tree-building approach to identify species uses monophyly as a criterion to discriminate taxa, while the system used to identify populations and individuals does not imply a hierarchical system of ancestor-descendant relationships (DeSalle et al., 2005). It is also important to underscore that coxl evolves at different rates in different taxa (Lessios and Ziegler, 2012), and therefore in some cases it may not be 
reliable as a phylogenetic marker. However, trees are still widely depicted in many DNA barcoding papers. Their best use is as a straightforward graphical depiction of the distance matrix found among different taxa (Fig. 10), summarising shared character states and distances among tree terminals (Goldstein and DeSalle, 2011), even though in the worst cases trees are represented simply because some referees ask for them.

\section{CONCLUSIONS}

In tardigrades, the use of DNA data is somewhat recent, but so far few attempts have been made at using DNA barcoding, mainly focusing on Macrobiotus species (Cesari et al., 2009, 2011; Bertolani et al., 2010, 2011a, 2011b), as most coxl data present in the literature are actually aimed for phylogenetic studies. A comprehensive list of DNA barcoded tardigrade species is available at http://www.tardigrada.modena.unimo.it. Considering also the difficulties in tardigrades to discriminate different taxa and the paucity of useful characters for taxonomy, we believe that an integrated approach should be implemented in future taxonomic studies in Tardigrada. This does not mean we reject classical morphological studies, but we do reject a species description only with DNA sequencing and without any morphological support. The production of sequence data paired with verified morphological specimens will build a trusted reference library that will help present and future researchers to build on knowledge of these fascinating animals.

\section{ACKNOWLEDGMENTS}

We are grateful to Dr. Paul Bartels (Warren Wilson College, NC, USA) for the English revision of the manuscript and his helpful suggestions. The research is part of the project MoDNA, supported by Fondazione Cassa di Risparmio di Modena (Italy) and by the University of Modena and Reggio Emilia (Modena, Italy).

\section{REFERENCES}

Barrett RDH, Hebert PDN, 2005. Identifying spiders through DNA barcoding. Can. J. Zool. 83:481-489.

Bertolani R, Biserov VI, Rebecchi L, Cesari M, 2011a. Taxonomy and biogeography of tardigrades using an integrated approach: new results on species of the Macrobiotus hufelandi group. Invertebr. Zool. 8:23-36.

Bertolani R, Giovannini I, Rebecchi L, Cesari M, 2011b. DNA barcoding and integrative taxonomy of Macrobiotus hufelandi C.A.S. Schultze 1834, the first tardigrade species to be described, and some related species. Zootaxa. 2997:19-36.

Bertolani R, Rebecchi L, Cesari M, 2010. A model study for tardigrade identification, p. 333-339. In: P.L. Nimis and R. Vignes Lebbe (eds.), Tools for identifying biodiversity: progress and problems. University of Trieste ed.

Carolan JC, Murray TE, Fitzpatrick Ú, Crossley J, Schmidt H, Cederberg B, McNally L, Williams PH, Brown MJ, 2012.
Colour patterns do not diagnose species: quantitative evaluation of a DNA barcoded cryptic bumblebee complex. PLoS One 7:e29251.

Casiraghi M, Labra M, Ferri E, Galimberti A, De Mattia F, 2010. DNA barcoding: a six-question tour to improve users' awareness about the method. Brief. Bioinform. 11:440-453.

Cesari M, Bertolani R, Rebecchi L, Guidetti R, 2009. DNA barcoding in Tardigrada: the first case study on Macrobiotus macrocalix Bertolani \& Rebecchi 1993 (Eutardigrada, Macrobiotidae). Mol. Ecol. Resour. 9:699-706.

Cesari M, Giovannini I, Bertolani R, Rebecchi L, 2011. An example of problems associated with DNA barcoding in tardigrades: a novel method for obtaining voucher specimens. Zootaxa 3104:42-51.

Clement M, Posada D, Crandall K, 2000. TCS: a computer program to estimate gene genealogies. Mol. Ecol. 9:1657-1660.

DeSalle R, 2006. Species discovery versus species identification in DNA barcoding efforts: response to Rubinoff. Con. Biol. 20:1545-1547.

DeSalle R, Egan MG, Siddall M, 2005. The unholy trinity: taxonomy, species delimitation and DNA barcoding. Proc. R. Soc. Lond. B 360:1905-1916.

Excoffier L, Laval G, Schneider S, 2005. Arlequin ver. 3.0: an integrated software package for population genetics data analysis. Evol. Bioinform. 1:47-50.

Faurby S, Jönsson KI, Rebecchi L, Funch P, 2008. Variation in anhydrobiotic survival of two eutardigrade morphospecies: a story of cryptic species and their dispersal. J. Zool. 275:139-145.

Faurby S, Jørgensen A, Kristensen RM, Funch P, 2011. Phylogeography of North Atlantic intertidal tardigrades: refugia, cryptic speciation and the history of the Mid-Atlantic Islands. J. Biogeogr. 38:1613-1624.

Ferri E, Barbuto M, Bain O, Galimberti A, Uni S, Guerriero R, Ferté H, Bandi C, Martin C, Casiraghi M, 2009. Integrated taxonomy: traditional approach and DNA barcoding for the identification of filarioid worms and related parasites (Nematoda). Front. Zool. 6:1.

Fontaine B, Bouchet P, van Achterberg K, Alonso-Zarazaga MA, Araujo R, Asche M, Aspöck U, Audisio P, Aukema B, Bailly N, Balsamo M, Bank RA, Barnard P, Belfiore C, Bogdanowicz W, Bongers T, Boxshall G, Burckhardt D, Camicas JL, Chylarecki P, Crucitti P, Deharveng L, Dubois A, Enghoff H, Faubel A, Fochetti R, Gargominy O, Gibson D, Gibson R, Gómez López MS, Goujet D, Harvey MS, Heller KG, van Helsdingen $\mathrm{P}$, Hoch $\mathrm{H}$, de Jong $\mathrm{H}$, de Jong Y, Karsholt O, Los W, Lundqvist L, Magowski W, Manconi R, Martens J, Massard JA, Massard-Geimer G, Mcinnes SJ, Mendes LF, Mey E, Michelsen V, Minelli A, Nieksen C, Nieto Nafría JM, van Nieukerken EJ, Noyes J, Pape T, Pohl H, de Prins W, Ramos M, Ricci C, Roselaar C, Rota E, Schmidt-Rhaesa A, Segers H, Zur Strassen R, Szeptycki A, Thibaud JM, Thomas A, Timm T, van Tol J, Vervoort W, Willmann R, 2007. The European Union's 2010 target: putting rare species in focus. Biol. Conserv. 139:167-185.

Galimberti A, Spada M, Russo D, Mucedda M, Agnelli P, Crottini A, Ferri E, Martinoli A, Casiraghi M, 2012. Integrated Operational Taxonomic Units (IOTUs) in echolocating bats: a bridge between molecular and traditional taxonomy. PLoS One 7:e40122. 
Goldstein PZ, DeSalle R, 2011. Integrating DNA barcode data and taxonomic practice: determination, discovery, and description. Bioessays 33:135-147.

Greenstone MH, Rowley DL, Heimbach U, Lundgren JG, Pfannenstiel RS, Rehner SA, 2005. Barcoding generalist predators by polymerase chain reaction: carabids and spiders. Mol. Ecol. 14:3247-3266.

Guidetti R, Gandolfi A, Rossi V, Bertolani R, 2005. Phylogenetic analysis in Macrobiotidae (Eutardigrada, Parachela): a combined morphological and molecular approach. Zool. Scr. 34:235-244.

Guidetti R, Rebecchi L, Bertolani R, 2000. Cuticle structure and systematics of the Macrobiotidae (Tardigrada, Eutardigrada). Acta Zool. 81:27-36.

Guidetti R, Schill RO, Bertolani R, Dandekar T, Wolf M, 2009. New molecular data for tardigrade phylogeny, with the erection of Paramacrobiotus gen. nov. J. Zool. Syst. Evol. Res. 47:315-321.

Guil N, Giribet G, 2009. Fine scale population structure in the Echiniscus blumi-canadensis series (Heterotardigrada, Tardigrada) in an Iberian mountain range. When morphology fails to explain genetic structure. Mol. Phyl. Evol. 51:606-613.

Hajibabei MHM, Shoakralla S, Zhou X, Singer GAC, Baird DJ, 2011. Environmental barcoding: a next-generation sequencing approach for biomonitoring applications using river benthos. PLoS One 6:e17497.

Hanner R, 2009. Data Standards for BARCODE Records in INSDC (BRIs). Available from: http://www.barcoding.si.edu/ PDF/DWG_data standards-Final.pdf

Hebert PDN, Cywinska A, Ball SL, DeWaard JR, 2003a. Biological identifications through DNA barcodes. Proc. R. Soc. Lond. B 270:313-321.

Hebert PDN, Penton EH, Burns JM, Jazen DH, Hallwachs W, 2004a. Ten species in one: DNA barcoding reveals cryptic species in the neotropical skipper butterfly Astraptes fulgerator PNAS 101:14812-14817.

Hebert PDN, Ratnasingham S, deWaard JR, 2003b. Barcoding animal life: cytochrome c oxidase subunit 1 divergences among closely related species. Proc. R. Soc. Lond. B 270(Suppl.1):S96-S99.

Hebert PDN, Stoeckle MY, Zemlak TS, Francis CM, 2004b. Identification of birds through DNA barcodes. PLoS Biol. 2:1657-1663.

Hogg ID, Hebert PDN, 2004. Biological identification of springtails (Collembola: Hexapoda) from the Canadian Arctic, using mitochondrial DNA barcodes. Can. J. Zool. 82:749754.

Hubert N, Delrieu-Trottin E, Irisson JO, Meyer C, Planes S, 2010. Identifying coral reef fish larvae through DNA barcoding: a test case with the families Acanthuridae and Holocentridae. Mol. Phylogenet. Evol. 55:1195-1203.

Kress WJ, Erickson DL, 2007. A two-locus global DNA barcode for land plants: the coding rbcl gene complements the noncoding trnH-psbA spacer region. PLoS One 2:e508.

Lambert DM, Baker A, Huynen L, Haddrath O, Hebert PDN, Millar CD, 2005. Is a large-scale DNA-based inventory of ancient life possible? J. Hered. 96:1-6.

Lara A, Ponce de León JL, Rodríguez R, Casane D, Côté G, Bernatchez L, García-Machado E, 2010. DNA barcoding of
Cuban freshwater fishes: evidence for cryptic species and taxonomic conflicts. Mol. Ecol. Resour. 10:421-430.

Lefébure T, Douady CJ, Gouy M, Gibert J, 2006. Relationship between morphological taxonomy and molecular divergence within Crustacea: proposal of a molecular threshold to help species delimitation. Mol. Phylogenet. Evol. 40:435-47.

Lessios HA, Zigler KS, 2012. Rates of sea urchin bindin evolution, p. 136-143. In: R.S. Singh, J. Xu and R.J. Kulathinal (eds.), Rapidly Evolving Genes and Genetic Systems. Oxford University Press.

Meier R, Shiyang K, Vaidya G, Ng PKL, 2006. DNA barcoding and taxonomy in Diptera: a tale of high intraspecific variability and low identification success. Syst. Biol. 55:715728.

Meier R, Zhang G, Ali F, 2008. The use of mean instead of smallest interspecific distances exaggerates the size of the "barcoding gap" and leads to misidentification. Syst. Biol. 57:809-813.

Moritz C, Cicero C, 2004. DNA barcoding: promise and pitfalls. PLoS Biol. 2:e354.

Packer L, Grixti JC, Roughley RE, Hanner R, 2009. The status of taxonomy in Canada and the impact of DNA barcoding. Can. J. Zool. 87:1097-1110.

Padial JM, Miralles A, de la Riva I, Vences M, 2010. The integrative future of taxonomy. Front. Zool. 7:16.

Paquin P, Hedin M, 2004. The power and perils of 'molecular taxonomy': a case study of eyeless and endangered $\mathrm{Circu}$ rina (Araneae: Dictynidae) from Texas caves. Mol. Ecol. 13:3239-3255.

Peterson AT, Moyle RG, Nyàri AS, Robbins MB, Brumfield RT, Remsen JV, 2007. The need for proper vouchering in phylogenetic studies of birds. Mol. Phylogenet. Evol. 45:1042-1044.

Pleijel F, Jondelius U, Norlinder E, Nygren A, Oxelman B, Schander C, Sundberg P, Thollesson M, 2008. Phylogenies without roots? A plea for the use of vouchers in molecular phylogenetic studies. Mol. Phylogenet. Evol. 48:369-371.

Rasmussen RS, Morrissey MT, Hebert PDN, 2009. DNA barcoding of commercially important salmon and trout species (Oncorhynchus and Salmo) from North America. J. Agr. Food Chem. 57:8379-8385.

Rubinoff D, Cameron S, Will K, 2006. Genomic perspective on the shortcomings of mitochondrial DNA for "barcoding" identification. J. Hered. 97:581-594.

Song H, Buhay JE, Whiting MF, Crandall KA, 2008. Many species in one: DNA barcoding overestimates the number of species when nuclear mitochondrial pseudogenes are coamplified. PNAS 105:13486-13491.

Srivathsan A, Meier R, 2011. On the inappropriate use of Kimura-2-parameters (K2P) divergences in the DNA-barcoding literature. Cladistics 28:190-194.

Tamura K, Peterson D, Peterson N, Stechler G, Nei M, Kumar S, 2011. MEGA5: molecular evolutionary genetics analysis using maximum likelihood, evolutionary distance, and maximum parsimony methods. Mol. Biol. Evol. 28:2731-2739.

Taylor HR, Harris WE, 2012. An emergent science on the brink of irrelevance: a review of the past 8 years of DNA barcoding. Mol. Ecol. Resour. 12:377-388.

Teacher AGF, Griffiths DJ, 2011. HapStar: automated haplotypes network layout and visualization. Mol. Ecol. Resour. 11:151-153. 
Templeton AR, Crandall KA, Sing CF, 1992. A cladistic analysis of phenotypic association with haplotypes inferred from restriction endonuclease mapping and DNA sequence data. III. Cladogram estimation. Genetics 132:619-633.

Vieites DR, Wollenberg KC, Andreone F, Köhler J, Glaw F, Vences M, 2009. Vast underestimation of Madagascar biodiversity evidenced by an integrative amphibian inventory. PNAS 106:8267-8272.

Ward RD, Zemak TS, Innes BH, Last PR, Hebert PDN, 2005.
DNA barcoding of Australia's fish species. Phil. Trans. R. Soc. Lond. 360:1847-1857.

Wiemers M, Fiedler K, 2007. Does the DNA barcoding gap exists? A case study in blue butterflies (Lepidoptera: Lycaenidae). Front. Zool. 4:8.

Zhang AB, Heb LJ, Crozier RH, Musterd C, Zhue CD, 2010. Estimating sample sizes for DNA barcoding. Mol. Phylogenet. Evol. 54:1035-1039. 